\title{
Transfer of Systems Analysis and Simulation in Agriculture to Developing Countries*
}

\author{
F. W. T. Penning de Vries \\ Multiple Cropping Department, International Rice Research Institute, \\ PO Box 933, Los Baños, Manila, Philippines \\ R. Rabbinge \\ Department of Theoretical Production Ecology, Agricultural University, \\ Wageningen, The Netherlands \\ D. M. Jansen \\ Centre for Agrobiological Research, Wageningen, The Netherlands \\ $\&$
}

A. Bakema

Waterloopkundig Laboratorium, Delft, The Netherlands

(Received 7 September 1987; accepted 1 October 1987)

\section{$A B S T R A C T$}

Systems analysis and simulation have developed into advanced tools in agriculture. They are used in research, extension and education. The recent

* The research for this publication was financed by the Netherlands Minister for Development Cooperation, who also shares copyright. Citation is encouraged. Short excerpts may be translated and/or reproduced without prior permission, on the condition that the source is indicated. For translation and/or reproduction in whole the Section for Research and Technology of the aforementioned Minister (P.O. Box 20061, 2500 EB The Hague) should be notified in advance.

Responsibility for the contents and for the opinions expressed rests solely with the authors; publication does not constitute an endorsement by the Netherlands Minister for Development Cooperation.

Agric. Admin. \& Extension 0269-7475/88/\$03.50 (C) 1988 Elsevier Applied Science Publishers Ltd, England. Printed in Great Britain 
availability of powerful inexpensive microcomputers now allows the use of these techniques in developing countries. A training programme was developed and conducted to enable the implementation of systems analysis and simulation in several national research institutes in South and Southeast Asia. Eight teams of four researchers from different disciplines participated in the training programme, which included a case study, involving both experimentation and computer simulation at their home institutes.

The evaluation indicated that this approach to training was effective. It is expected to be applicable on a wider scale. The interactions between team members from different disciplines were strengthened by the course experiences. Simulation provided a means and a reason for communication. However, reaching the ultimate goal of systems analysis and modelling at these national research institutes, i.e. to use these tools to contribute toward increased national agricultural production, is expected to require several years.

\section{INTRODUCTION}

'Transfer of knowledge and technology' is an expression much heard in discussions on development of countries that are still poor and have a shortage of personnel skilled in agricultural research, education and extension. At least two aspects of technology transfer need special attention: the technology may not be functional in the other country because of its different environment, and the transfer itself may be difficult to realize because technology implementation requires more than manuals, tools and local tests. ${ }^{10}$ Is systems analysis and simulation a technique that can and should be transferred to developing countries?

System analysis and simulation is a technique with wide implications. It requires an explicit conceptualization of an agricultural production system. This helps to define what quantitative knowledge is needed and from what scientific disciplines that knowledge should be derived. It stimulates the integration of contributions from basic sciences in such a way that the functioning of the system is better understood. We present here an overview of a training programme which involved a new approach to the transfer of systems analysis and simulation to developing countries, and we discuss the results and implications of this experience.

The ultimate objective of the training programme was 'to develop a network for agrobiological research in developing countries that combines simulation and experimentation and helps to determine the potentials of primary and secondary production under different circumstances in different regions. This type of information is one of the keystones of each agricultural development program'. ${ }^{1}$ 
The immediate objectives were the development and the presentation of a training programme on modelling and simulation of rice production. This required providing technical backstopping for the teams for an extended period after the formal course ended. The course and the activities were directed towards scientists from national research stations and agricultural universities. It instructed them on how modelling can improve their research and extension work on rice production.

\section{BACKGROUND AND BASIS}

The development and use of systems analysis and simulation for agricultural research in general, and especially for crop production research, has been undertaken by the Department of Theoretical Production Ecology (TPE) of the Agricultural University in Wageningen since its initiation in 1969, led by C. T. de Wit.

Formalization of training for undergraduate students led to one of the first of a series of Simulation Monographs, containing a full training course with lectures and exercises: 'Simulation of Ecological Processes'. ${ }^{3}$ Postgraduate courses started in 1977 in response to a growing demand. Interest in specific courses also grew outside The Netherlands. An international postgraduate course on 'Simulation of Plant Growth and Crop Production' was held in Wageningen in $1980^{\circ}$ and repeated in Venezuela at the Instituto Internacional de Estudios Avanzado, ${ }^{2}$ and in Sofia at the Poushkarov Institute in 1985. An international course on Simulation and Systems Management in Crop Protection was given in Wageningen $(1980,1982,1986)$ and in Helsinki (1987), while at the request of the World Meteorological Organization, a postgraduate course was given on 'Modelling of Agricultural Production'. ${ }^{11}$ The work of TPE has been at the core of these courses, but contributions by other research organizations and university departments were crucial to the breadth of the topics presented. The courses held outside Wageningen were fully financed by the receiving institutes.

Most of the participants were enthusiastic about the courses (over 80 per cent), but found little possibility to use the newly acquired skills in their home institutes. This applied particularly to participants from developing countries, but also to those from developed countries. Several constraints were identified: too short a training period, no follow up from the course organizers, no computers at the home institute to perform simulation, and too little motivation and support at home to pursue the application of the new methodology. For an effective transfer of systems analysis and simulation, the method of transfer needed adjustment. 
Another development also led also to a reconsideration of the form of the postgraduate training. The volume of knowledge about crop production and related processes has increased substantially during the last decade. This has brought about a rapidly increasing use of quantitative and mathematical techniques in the agricultural sciences, including simulation. Some simulation models have been sufficiently developed to be used as advanced research tools in related disciplines, and for practical applications, such as land use planning ${ }^{5}$ and farm crop management. ${ }^{13}$ The growth in the volume of basic data that are inputs for models, such as weather ${ }^{6}$ and soils data, further strengthens the applicability of such models. Simulation techniques have therefore become more applicable in practice. The Centre for Agrobiological Research (CABO) in Wageningen, in collaboration with TPE, has executed since 1972 several research projects in developing countries: Israel, Mali, Peru, Egypt. Systems analysis has played an important role in those projects. They were aimed at the identification and quantification of key limiting factors or processes for agricultural production. $^{8,12}$

Finally, the introduction of powerful yet inexpensive microcomputers allows the use of computerized quantitative techniques on a wide scale. They are rapidly becoming common in almost every country.

The experiences with training courses, the improvements in models and data bases, and the larger availability of computers led us to attempt a new method of knowledge transfer to developing countries.

\section{THE CABO-TPE-IRRI PROJECT}

$\mathrm{CABO}, \mathrm{TPE}$ and the International Rice Research Institute (IRRI) have collaborated in an effort to make better use of existing models about crops in general and of data about rice production in particular. ${ }^{1}$ An important aim was to put the combined knowledge and data into a form that would be really accessible for many scientists and be of practical use to workers in agricultural research in developing countries.

A training programme was executed (1985-87) with the following characteristics:

(A) Instruction was given to teams of four persons from a single organization rather than to individuals from different organizations. Team members were from related, but different, scientific disciplines (e.g. crop physiology, agronomy, soil science, entomology). It was emphasized that every team member would acquire the basic skills in systems analysis, simulation and computer use. In practical exercises, a certain degree of specialization was encouraged. 
Nine institutes and universities with potential teams were approached. Selection of these organizations was on the basis of their staff strengths and mandates, their links with IRRI, and expectations about the impact of results at the institute. Seven organizations responded positively, while IRRI added one team of its own. All the teams participated in the entire training. The organizations were asked to send team members with an MSc or PhD degree and some years of job experience, and all organizations except two were able to comply with this suggestion. Explicit mathematical experience or computer skill was not demanded. It was agreed with the supervisors that the members could work as a team during the one year training programme and possibly also later on.

(B) Four phases in the training project were distinguished.

1. Preparation before the formal course started with two project staff members visiting the teams 2-4 months prior to the course. This permitted them to explain to the teams and their supervisors the training objectives and methods, and to ask their agreement for collaboration during and after the project. Team members received some study material, which most did not read, and were asked to collect specific environmental data, which was largely done. The visits also gave information about the background and experience of team members.

2 . The formal course work lasted two months, with roughly 40 per cent of contact time in lectures, 40 per cent in exercises, 10 per cent in excursions to laboratories, and 10 per cent in other activities. The course was held in Wageningen. The topics were presented in eight blocks: Introduction; Systems Analysis; Crop Physiology; Soil Water Balance; Nutrients, Diseases and Pests and Weeds; Cropping Systems; Case Study Preparation. (Details of the entire syllabus and lecture content are available on request.)

3. Each team executed a case study of about eight months at their home base on a topic relevant to their institute and one which was practicable considering the models available and the skills gained. These research projects studies consisted of simulation studies, literature review and field experiments. The actual time spent on the case study is difficult to quantify since it was highly variable, but it was estimated to be on average half of the research time of the individuals concerned (as had previously been agreed upon). The research topics of the respective groups were also quite different (Table 1). During this period, contacts were maintained with the project staff through Progress Reports and Newsletters. Each team was visited at least once by a project staff member.

4. A training workshop was held at IRRI, including all participants, to review the case study reports and to evaluate the training project. The team supervisors were invited and six participated in the evaluation. The reports ${ }^{4}$ show results of well-conducted interdisciplinary experiments that fitted the 
TABLE 1

Teams and Case Studies

\begin{tabular}{|c|c|c|c|}
\hline Country & University/Institute & Case study title & Disciplines \\
\hline \multirow[t]{2}{*}{ India } & $\begin{array}{l}\text { Pantnagar University, } \\
\text { Pantnagar }\end{array}$ & $\begin{array}{l}\text { Potential production of rice in Uttar Pradesh, and the effect } \\
\text { of several crop management techniques (planting dates, } \\
\text { cultivars, nitrogen). }\end{array}$ & $\begin{array}{l}\text { Agronomy, breeding, soil } \\
\text { science, pathology }\end{array}$ \\
\hline & $\begin{array}{l}\text { Central Rice Research } \\
\text { Institute, Cuttack }\end{array}$ & $\begin{array}{l}\text { Exploration of possibilities for yield improvement under low } \\
\text { light in Eastern India, and estimation of damage caused by } \\
\text { leaf blight. }\end{array}$ & $\begin{array}{l}\text { Physiology, agronomy, plant } \\
\text { protection }\end{array}$ \\
\hline Indonesia & $\begin{array}{l}\text { Sukarami Research Institute } \\
\text { for Food Crops, Padang, } \\
\text { West Sumatra }\end{array}$ & $\begin{array}{l}\text { Epidemiology of leaf blast under various abiotic and biotic } \\
\text { conditions. }\end{array}$ & $\begin{array}{l}\text { Breeding, pathology, } \\
\text { agroclimatology, statistics }\end{array}$ \\
\hline Malaysia & $\begin{array}{l}\text { Universiti Pertanian } \\
\text { Malaysia, Kuala Lumpur }\end{array}$ & $\begin{array}{l}\text { Influence of planting density on assimilate partitioning and } \\
\text { yield of rice. }\end{array}$ & $\begin{array}{l}\text { Physiology, agronomy, } \\
\text { entomology, soil science }\end{array}$ \\
\hline \multirow[t]{2}{*}{ Philippines } & $\begin{array}{l}\text { University of the Philippines, } \\
\text { Los Banos }\end{array}$ & $\begin{array}{l}\text { Effect of frequency and timing of weeding on yield of rainfed } \\
\text { rice in Los Banos, Laguna; evaluation of effects of drought } \\
\text { on potential yield of rainfed rice. }\end{array}$ & $\begin{array}{l}\text { Biology, hydrology, } \\
\text { entomology, soil science }\end{array}$ \\
\hline & $\begin{array}{l}\text { International Rice Research } \\
\text { Institute, Los Banos }\end{array}$ & $\begin{array}{l}\text { Potential production under different weather conditions; } \\
\text { upland rice crop growth under varying water table depth; } \\
\text { effects of yellow stemborer and leaffolder on rice. }\end{array}$ & $\begin{array}{l}\text { Agronomy, entomology soil } \\
\text { science, statistics }\end{array}$ \\
\hline Sri Lanka & $\begin{array}{l}\text { Regional Agricultural } \\
\text { Research Centre, } \\
\text { Bombuwela }\end{array}$ & $\begin{array}{l}\text { Simulation of the potential production of rice in the low } \\
\text { country wet zone; effects of iron toxicity and sheath blight } \\
\text { on potential yield. }\end{array}$ & $\begin{array}{l}\text { Agronomy, breeding, } \\
\text { entomology }\end{array}$ \\
\hline Thailand & $\begin{array}{l}\text { Khon Kaen University, } \\
\text { Khon Kaen }\end{array}$ & $\begin{array}{l}\text { Timing and duration of the growing season for rice and the } \\
\text { crop after rice in North East Thailand; simulation of yield } \\
\text { loss due to stemborer. }\end{array}$ & $\begin{array}{l}\text { Crop physiology, agronomy, } \\
\text { soil science, entomology }\end{array}$ \\
\hline
\end{tabular}


objectives. Interpretation and extrapolation of the results with simulation was extensive and scientific in quality in several groups, but was less complete in other groups for lack of time, computer breakdown, or lack of skill.

(C) Supervisors (i.e. directors of the institutes, vice-chancellors of the universities or equivalent positions) were directly involved in the first and final step of the training project.

(D) One personal computer (IBM PC/AT) was given to each team, large enough to allow full-scale simulation. A well-documented simulation language (CSMP), used extensively for crop growth modelling, was adapted to run on this $\mathrm{PC}$ from a minicomputer version.

Preparations for the training project required about one year by two fulltime junior scientists with intensive guidance and support from the peer institutes (CABO, TPE, IRRI). The period after the formal course required an effort of a similar magnitude. Fourteen scientists lectured more than once in this course, though 60 per cent of the lectures and almost all of the exercises and assistance during practicals were supplied by the junior scientists, two peers and one assistant.

\section{EVALUATION OF THE TRAINING PROJECT}

The final goal of this project, to accelerate agricultural research in participating institutes, is not expected to be reached for several years. After adoption of system analysis and simulation, it takes several years of work before it can be shown that agricultural research has increased in depth and impact. Conclusions about the effectiveness of this training project are therefore provisional.

An evaluation of the training project was explicitly conducted with all participants and with team supervisors. Scores on key questions on the evaluation forms are given in Table 2 . The strong points, as perceived by the trainees and supervisors, were:

-inducing team members to move out of their own scientific field and to discuss topics in quantitative terms with colleagues;

-modelling stimulates communication by urging all involved to make their hypotheses and assumptions, and to quantify knowledge;

-the use of scientific knowledge in the form of models for relatively practical studies: participants remarked that the modelling studies had more practical implications than they had expected. 
TABLE 2

Some Questions and Answers on Evaluation of the Training Programme from 31 Workshop Participants

A. Effects of the training

To what extent has this training programme contributed

1. To your interdisciplinary research?

2. To your integration of knowledge?

3. To formulate research at process and systems levels?

4. To implement systems analysis and simulation in future research?

5. To understand better crop production?

(average score of one or of several related questions on a scale of 1 (little) to 5 (high)).

B. Training programme curriculum

1. Would you prefer to change the overall programme structure (components, sequence)?

Yes $\quad 6$

No 47

2. Was the team approach actually effective?

Yes $\quad 72$

3. In the formal course, was the quantity satisfactory?

Theory and lectures

Practicals

Preparation case study

4. Which of the 8 topics in the formal course were most useful?

Crop physiology, rice model

Methodology

Case study preparation

Nutrients, pests and diseases

$\begin{array}{ccc}\text { Too much } & \text { OK } & \text { Too little } \\ 8 & 13 & 5 \\ 1 & 14 & 36 \\ 0 & 11 & 15\end{array}$

5. Which of the 8 topics need more emphasis?

Methodology

None

Other blocks

(score is total from 1 (number 3a, 3c, 5), $2(1,3 b, 4)$ or 3 questions (2)).

C. Future research

1. Considering the long investment, do you expect your supervisor to send another team, when available, to a similar course?
Answers
Yes
$27 \quad$ No
2

2. Will you use a model received in the training in future work?

Answers $\quad$ Yes 21

A new one 4

A new one, later 3

Another 1

3. Has this training programme contributed to international co-operation?
Answers
Yes
29 Not yet 1

4. How long do you expect your team to maintain contacts with the training organizers?

$\begin{array}{lll}\text { Answers } & 2 \text { years } & 3 \\ & 3-4 \text { years } & 8 \\ & \text { Longer } & 6\end{array}$

(scores are totals of one question each) 
Weak points in the project appeared to be:

- the preparatory phase had little effect;

- course texts and simulation programs were insufficiently complete, consistent and balanced;

- the formal course in Wageningen was too short (though teams would have declined the invitation to participate if it had been longer);

- the period available for the case studies was short;

- computer programs and the PCs produced technical problems which in some instances required several months to solve.

The overall conclusion of the evaluation was that the immediate objectives of the training programme were largely reached. This has already led to a second collaborative training and research project between the same institutes, in which the teams from the first course will collaborate and new teams will be formed. Research at CABO, TPE and IRRI will further reinforce the modelling approach and data base.

Which elements contributed most to this success? Particularly, it was the team approach and the case studies.

The team approach was successful. Every team stated this. The reasons included mutual motivation, mutual support and the multidisciplinarity as such. One team can be the critical mass needed to start systems analysis and simulation at an institute. When team members retain their interaction, the binding force will remain effective. A simulation model common to all team members is expected to continue to provide a solid basis for co-operation. Positive practical results, expected after several years of work, will add to this. Yet, individual contributions to team work should also be explicit and recognized. In one or two teams, all members had almost the same task of developing the model and of experimentation. In others, tasks were more partitioned according to interest or background. The latter teams were generally more successful and productive. This points to two contrasting interests for individuals: the benefit of working with colleagues towards a common goal, and the need to be recognized as an independent person and scientist. Distribution of tasks implies also the identification and distribution of responsibilities. One team created a clear and effective internal structure for joint and individual tasks and responsibilities. It is expected that teams will remain together and productive when:

- members benefit professionally from frequent contacts with other team members. Simulation models can be an important means to achieve this;

- a common goal is formulated, including ultimate and immediate objectives;

- the personal contributions of team members remain a recognizable part of the entire effort. 
We can confirm from our own experience in simulation groups that these elements are essential in simulation teams ${ }^{7}$ (and possibly in any voluntary team effort).

The case studies were clearly an essential part of the training project. They involved the application of the new skills and implementation at home, largely independent of the project staff. These studies revealed several insights for participants and for organizers. In choosing the topic(s) and specifying the objectives, much more time was spent in carefully formulating the case studies than was planned: on average five full days per team. In particular, the formulation of achievable and yet attractive objectives took much effort. ${ }^{7}$ The limitations of models and knowledge, but also their implicit possibilities then became clearer. The formulation of team case studies should not receive less attention in succeeding courses (see also Table 2).

All the case studies were unique (Table 1). This appeared to be undesirable as it made communication and exchange of experience between teams difficult. It is probably better to split case studies into two topics: one similar for all teams (such as 'potential production in one's own country') and a second one specific to each team's interests.

Many participants continued to be hesitant to modify the program structure of the models during the case study, and to a lesser extent also to change data. This indicates that they had not fully assimilated the contents of the models and their programming. Project staff visits during the case studies appeared a stimulating and effective way to improve this. The need for maintaining contacts for several years between the teams and project staff was underlined (Table 2).

There are a few other comments arising from the evaluation relevant to this paper. The preparatory phase before the course was not very effective for various reasons (low expectations, too little time, difficult reading material). Insufficient preparation caused a slow start and later on led to a shortage of time. The course and evaluations showed clearly, however, that this phase is required for most participants to bring them up to data or to refresh their knowledge, particularly in the basic principles of mathematics, systems analysis and the principles of each of the scientific disciplines involved.

Comments were invited concerning how to improve the course content and materials. Several lectures about other crop growth models were given during the formal course. This often brought confusion rather than the anticipated broadening of views on modelling. However, lectures to present the application of modelling in other disciplines, such as agricultural economics, were appreciated. The rating of the importance of individual sections of the course was mostly positive, although it varied considerably among participants. This is related to their background and underlines 
again the importance of better preparation. In an interdisciplinary training programme it is almost unavoidable that some topics that need treatment for most participants are already well known to others.

\section{CONCLUSIONS}

The interdisciplinary team approach to training in systems analysis and simulation of crop production appeared to be stimulating and effective in so far as this can at present be established. Although a thorough basis in modelling was obtained by most participants during the formal course and the case study, they did not become fully technically independent. Interaction with project staff and other teams are still needed for several years.

For the teams to work effectively, it is important that the level of strategic and adaptive research in their home institute permits the new techniques to be absorbed. This will be one of the selection criteria for new teams.

Modelling is an effective communication tool between the disciplines involved: participants are challenged to translate and (re)formulate their own problems into a systems analysis framework. Prejudices are replaced by explicit and quantitative assumptions, hypotheses and facts. This is an intellectually demanding, and also a rewarding, task.

Future courses can be given with a similar outline. Their effectiveness can be further enhanced by improving the course materials and by better preparation of the teams. Execution of the case studies reinforced the adoption of systems analysis and improved the ability of participants to use it. This element in the training should receive more attention in a next course. More effective course materials could include computer-aided instruction for introductory topics, models and exercises. These tools are still to be developed.

Because the approach and much of the scientific substance in this training project was not specific to the rice crop, it seems feasible to apply this method of knowledge transfer to other crops and other disciplines in agriculture.

\section{ACKNOWLEDGEMENTS}

Dr M. S. Swaminathan (IRRI) suggested bringing crop simulation to National Agricultural Research Centres in developing countries in the form of a course. Dr R. A. Morris (IRRI) provided much help in organizing the training programme. N. van Keulen, H. Rodenburgh (CABO) and R. Dierkx (TPE) assisted in the preparation of course materials. Drs M. Rosegrant 
(IFPRI) and D. P. Garrity (IRRI) gave lectures and helped in formulating case studies. L. Kanbier (TPE) assisted one team in their case study research. D. P. Garrity co-organized the workshop at IRRI. A. A. Silva (IRRI) assisted in preparing the workshop publication. Support by Ir H. Gunther (TPE), Ir J. Van der Lek (CABO) and D. Minnick (IRRI) during the evaluations is kindly acknowledged.

\section{REFERENCES}

1. CABO, Implementation of systems analysis, and simulation in rice production, June 1984 version. CABO, P.O. Box 14, Wageningen, The Netherlands, 1984.

2. Cordova, J., Penning de Vries, F. W. T. \& van Laar, H. H., Modelling of crop production: evaluation of an international post graduate course held at IDEA, November 1982. Simulation Reports CABO-TT, No. 2, CABO, P.O. Box 14, Wageningen, The Netherlands, 1983.

3. De Wit, C. T. \& Goudriaan, J., Simulation of ecological processes. Simulation Monographs, Wageningen, The Netherlands, PUDOC, 1978.

4. IRRI, Case studies in crop growth simulation. Multiple Cropping Department. P.O. Box 933, Manila, Philippines, 1987.

5. Kingwell, R. S. \& Pannell, D. J. (Eds), MIDAS, a bioeconomic model of a dryland farm system. Simulation Monograph. Wageningen, The Netherlands, PUDOC, 1987.

6. Oldeman, L. R., Seshu, D. V. \& Cady, F., Response of rice to weather variables. In: Impact of weather parameters on the growth and yield of rice (Seshu, D. V. (Ed.)), Los Baños, Philippines, IRRI (in press).

7. Penning de Vries, F.W. T., Evaluation of simulation models in agriculture and biology, conclusions of a workshop. Agricultural Systems, 2 (1977), 99-107.

8. Penning de Vries, F. W. T. \& Djiteye, M. A., La productivite des paturages saheliens. Agric. Res. Rep., 918, Wageningen, The Netherlands, PUDOC, 1982.

9. Penning de Vries, F. W. T. \& van Laar, H. H., Simulation of plant growth and crop production. Simulation Monograph. Wageningen, The Netherlands, PUDOC, 1982.

10. Schware, R. \& Trembour, A., Rethinking microcomputer technology transfer to third world countries. Science and Public Policy, 12(1) (1985), 15-20.

11. Van Keulen, H. \& Wolf, J., Modeling of agricultural production: Weather, crops and soils. Simulation Monograph. Wageningen, The Netherlands, PUDOC, 1986.

12. Versteeg, M.N., Factors influencing the productivity of irrigated crops in Southern Peru in relation to prediction by simulation models. Ph.D. thesis, Agricultural University, Wageningen, The Netherlands, 1985.

13. Zadoks, J. C., Rijsdijk, F. H. \& Rabbinge, R., EPIPRE: A systems approach to supervised control of pests and diseases in wheat in The Netherlands. In: Pest and pathogen control: Strategic, tactical and policy models (Conway, G. R., (Ed.)) International Series on Applied Systems Analysis. Wiley and Sons, Chichester, 1984. 